\title{
Talk show: um gênero televisivo entre o jornalismo e 0 entretenimento
}

Fernanda Mauricio Silva

\section{Resumo}

Enquanto nos países de língua inglesa o termo

"talk show" é utilizado para designar programas, jornalísticos ou não, que têm a conversa entre participantes como marca central, no Brasil, a nomenclatura "talk show" representa um corte entre a esfera do jornalismo e do entretenimento. 0 objetivo do presente artigo é resgatar historicamente o surgimento do gênero talk show no Brasil e demonstrar analiticamente os elementos que 0 configuram enquanto gênero televisivo por meio da observação do Programa do Jô (rede Globo). A recuperação histórica visa demonstrar seu desdobramento a partir dos programas de entrevistas e os fatores sócio-culturais da sociedade brasileira que permitiram o borramento de fronteiras entre informação e entretenimento, hoje comumente chamado de infotainment. A análise do programa levará em consideração o conceito de modos de endereçamento, pensado enquanto tom e estilo do programa.

Palavras-chave

Talk show. Gênero televisivo. Infotainment.

Fernanda Mauricio Silva | fernandamauricio@gmail.com Doutoranda pelo Programa de Pós-graduação em Comunicação e Cultura Contemporâneas da Universidade Federal da Bahia - UFBA.

\section{0 talk show: um gênero televisivo}

0 termo "talk show" se popularizou no Brasil no final dos anos 1980 a partir da tradição televisiva norte-americana que o emprega para designar qualquer programa que utiliza a conversação como base estruturante. Programas de entrevistas, com ou sem a presença de uma plateia, e programas de debate se incluem nessa nomenclatura. Modelo proveniente do rádio, os talk shows nasceram nos Estados Unidos nos anos 1950, cobrindo três faixas majoritárias da programação: pela manhã, os talk shows se dedicavam majoritariamente às notícias; no horário vespertino, eram os programas de debate com forte ênfase no aconselhamento; na programação noturna, os talk shows dedicaramse ao humor e às entrevistas com celebridades (TIMBERG, 2004). Foi desta forma que os talk shows garantiram às emissoras um aumento significativo da audiência e a formação de um segundo prime time (MATEU, 1998).

A proliferação desse formato na programação televisual norte-americana e europeia (após os anos sessenta) evidenciou características 
marcantes de um gênero próprio que aparecia como elemento emergente (WILLIAMS, 1979) no fluxo televisivo. Pensar o talk show enquanto gênero televisivo à luz dos Estudos Culturais significa pensá-lo como estratégia de comunicabilidade que serve tanto como modelo de escritura, quanto de horizonte de leitura (BARBER0, 1997, p. 302) que se atualizam nos programas específicos. Sendo assim, no processo comunicacional, o gênero é uma "estratégia de interação" (GOMES, 2007) que integra produção e audiência no mesmo processo. 0 gênero televisivo cria parâmetros de reconhecimento os quais os telespectadores irão acionar ao se colocar diante de um representante do mesmo. Daí que The Phil Donahue Show, The Jerry Springer Show, The Oprah Winfrey Show e The Tonight Show with Jay Leno são produtos que partilham normas de produção comuns e despertam formas de recepção específicas.

A consolidação do talk show no cenário televisivo e a efetivação de um formato próprio se deu de maneira gradual, a partir de relações que se estabeleciam entre 0 gênero e a sociedade. Portanto, os gêneros televisivos não são uma estrutura rígida, mas modificam-se em função das transformações na política, economia, tecnologia, cultura, e de novas demandas que emergem no público.
No início de suas transmissões, os programas de talk show eram mais ligados à informação, com a finalidade de "verificar dados, obter valorações ou pronunciamentos sobre um fato da atualidade ou sobre um personagem que é notícia; enfim, trata-se de conhecer aspectos novos a partir do diálogo com os entrevistados" (MATEU, 1998, p. 151). Nesses casos, os talk shows eram tidos como representantes do campo jornalístico, comprometido com o interesse público, a dimensão de vigilância e com a esfera pública, num sentido mais habermasiano ${ }^{1}$. Henrik Örnebring (2003) demonstra que, durante o período de 1956 a 1968, os talk shows vivenciaram a fase do "debate cortês", cuja finalidade era educar a população. Para isso, políticos, representantes de organizações, jornalistas e professores compartilhavam seu conhecimento a fim de ampliar o repertório cultural da audiência.

No entanto, esse modelo de talk show convivia na grade de programação com programas que acolhiam elementos mais vinculados ao entretenimento a partir de deslocamentos efetuados com pelo menos dois outros gêneros ${ }^{2}$. Da stand-up comedy, gênero teatral no qual um comediante atua diante de uma plateia fazendo piadas, o talk show se apropriou do modelo de apresentação, baseada num apresentador-

0 programa See It Now, comandado por Edward Murrow, representado no filme Boa Noite e Boa Sorte (2005) é um bom exemplo desse modelo de talk show.

É de François Jost (2004b) a idéia de que os gêneros também são afetados pela relação uns com os outros na grade de programação, podendo dialogar com mundos distintos combinando-os: realidade, ficção e ludicidade. 
estrela que conta piadas e entretém o público.

Dos programas de auditório, o talk show extraiu a plateia que participa da cena por meio de aplausos, risos, vaias e, em alguns casos, de perguntas para os integrantes no palco.

Na Europa, o surgimento das televisões privadas oferecendo concorrência às emissoras públicas parece ter motivado essa migração de gêneros, estabelecendo novos formatos e conteúdos a esses programas (MATEU, 1998; ÖRNEBRING, 2003), fator que se acirrou após os anos oitenta. Foi após esse momento que a pornografia, as brigas entre maridos e esposas, a infidelidade tornaram-se a temática desse tipo de programa.

Se por um lado a proximidade com 0 entretenimento permitiu a degradação de certos valores, por outro ele permitiu que temas externos ao campo jornalístico pudessem ser discutidos socialmente, voltando a atenção para a cotidianidade e a subjetividade. Segundo Sonia Livingstone e Peter Lunt (1994) os programas de talk show reconfiguraram o sentido dominante de esfera pública, permitindo que as pessoas comuns tivessem seus assuntos mais pessoais discutidos e esclarecidos. Segundo os autores, os talk shows

[...] não são sobre current affairs ou assuntos de consumo, mas eles lidam com assuntos cotidianos à medida que afetam a vida ordinária. [...] Eles trazem questões além do domínio privado do ambiente doméstico e do local, já que o telespectador é também construído como cidadão, com um dever de ser informado acerca do mundo e de agir sobre ele (1994, p. 38-39).
Foi na proximidade com a lógica do

entretenimento televisivo que os talk shows ganharam mais popularidade e maior audiência.

Embora 0 sentido informativo inicial tenha permanecido residualmente na programação televisiva, recentemente o termo "talk show" tem sido empregado de maneira depreciativa por afigurar uma interseção pejorativa entre informação e entretenimento, comumente chamada de infotainment. Segundo Richard Shusterman (2003), desde seus usos mais remotos o termo "entretenimento" esteve associado à distração, ao lazer, ao prazer. Em oposição ao conhecimento filosófico, 0 entretenimento forneceria distração das coisas realmente sérias. No século XVIII, autores como Heidegger e principalmente Hegel, na discussão sobre a estética, separaram a racionalidade, embutida na fruição da arte, da distração provocada pela arte popular, argumento que foi ratificado pelos autores da Escola de Frankfurt na cisão entre alta cultura e baixa cultura - a cultura popular massiva - cabendo à primeira o exercício intelectual, e à segunda a distração e 0 prazer. Portanto, o entretenimento e todas as suas derivantes - prazer, divertimento $\mathrm{e}$ distração - foram dissociados das esferas sérias da sociedade, dentre as quais o jornalismo reivindica um lugar.

Foi também após o século XVIII e principalmente no século XIX que o jornalismo constituiu-se como esfera da racionalidade. Ao fortalecer-se como instituição social, o jornalismo tornou-se 
responsável por ser o porta-voz dos assuntos sérios, daquilo que era realmente importante para a sociedade: política e economia. Tal postura configurou-se no modelo dominante de jornalismo, marcado pelo paradigma da objetividade (a não-opinião e não-emoção do repórter $^{3}$ ), de um estilo textual caracterizado pela "pirâmide invertida" e o privilégio de fatos em detrimento das opiniões. Outras formas de jornalismo que se desenvolveram no mesmo período - o sensacionalismo, por exemplo - eram consideradas práticas depreciadas, inferiores, populares ${ }^{4}$.

É 0 campo jornalístico, portanto, que procura legitimar-se socialmente como um "nãoentretenimento", buscando desassociar de sua linguagem qualquer relação com 0 entretenimento. No entanto, nas hibridações dos gêneros televisivos, os programas de talk show não se apartam completamente dos aspectos do campo jornalístico, sobretudo no Brasil, em que o surgimento dos programas de talk show, em especial do Jô Soares Onze e Meia, está associado a um período de transição em que a sociedade demandava dos produtos culturais aprofundamento das informações e diversão.
É nesse sentido que pretendemos pensar os talk shows como um gênero televisivo diferenciado no Brasil. A partir de um resgate histórico, é possível compreender a vinculação com os programas de entrevistas que lhes deram origem e, por conseguinte, com valores do campo jornalístico que são reivindicados como fatores de legitimação deste gênero na grade televisiva. Posteriormente, pretendemos evidenciar, por meio da análise dos modos de endereçamento do Programa do Jô (Globo), as marcas constitutivas deste gênero.

\section{0 desenvolvimento dos talk shows no Brasil}

0 "talk show" no Brasil surgiu após a consolidação de outro gênero, ou melhor, subgênero televisivo ${ }^{5}$ : os programas de entrevistas. Sendo assim, os dois gêneros não se confundem numa mesma terminologia, como ocorre nos Estados Unidos e Europa. Foi no contexto do abrandamento da censura imposta pelo regime militar e do advento de novas tecnologias da comunicação que o telejornalismo se dinamizou, criando novos formatos na grade de programação com um conteúdo até então refutado pelos telejornais. Nesse ínterim, as emissoras brasileiras de televisão levaram ao

Ver Guerra (2003).

Vale ressaltar que popular, nesse sentido, opõe-se à racionalidade da cultura erudita, sentido que foi privilegiado na consolidação do campo jornalístico. Para uma discussão sobre o jornalismo popular á luz dos Estudos Culturais, ver Dalghren, 2000.

Segundo Itania Gomes (2007), os subgêneros são variações dentro do gênero. No exemplo supracitado, referimo-nos aos programas de entrevista, variação do gênero programas jornalísticos, juntamente com telejornais, programas de jornalismo temático, documentários, programas de debate etc. 
ar os primeiros programas de entrevistas, tendo como expoentes desse período o Abertura $^{6}$ (TV Tupi) e posteriormente o Canal Livre (TV Bandeirantes), dirigidos por Fernando Barbosa Lima (REZENDE, 2000). Nos dois casos o foco temático dos programas era dar visibilidade a assuntos e personalidades do campo da política que não tinham espaço na televisão até então. No início na década de oitenta, esse gênero televisivo pareceu se consolidar na grade de programação nacional, com programas como Cara-a-Cara com Marília Gabriela (Band, 1985).

Com o processo de redemocratização do Brasil, o telejornalismo também se reestruturou. Em 1981, duas novas emissoras figuravam o quadro das comunicações no Brasil: a TV Manchete, do grupo Bloch, e o Sistema Brasileiro de Televisão (SBT), comandado por Sílvio Santos. Durante a década de oitenta, as manifestações pelas Diretas Já e pela sucessão de José Sarney mantinham 0 nível de expectativa da audiência com relação aos programas jornalísticos no mesmo patamar: o público cobrava análise crítica dos fatos - 0 que foi feito pela TV Manchete, que ousou levar ao ar duas horas de telejornalismo no horário nobre (REZENDE, 2000, p.122). 0 SBT, por sua vez, demonstrava uma inclinação maior para programas populares de entretenimento, como os programas de auditório, telenovelas mexicanas, games e programas de fofocas. Em 1988, Sílvio Santos provocou uma virada no telejornalismo nacional ao contratar Boris Casoy como âncora do TJ Brasil, um telejornal voltado para a análise dos fatos e comentários feitos pelo apresentador. Assim, mesmo no SBT, havia uma preocupação em atender às demandas da audiência por um modelo de jornalismo mais engajado naquele período histórico.

Também em 1988, o SBT levou ao ar o primeiro talk show da televisão brasileira, o Jô Soares Onze e Meia. Seguindo o modelo norte-americano de estruturação do cenário e pegando aquilo que parecia ser o elemento central do gênero - a informação com humor -, o Jô Soares Onze e Meia, embora recolhesse elementos do humor que ficavam nítidos na performance de seu apresentador, estava em conformidade com a proposta do jornalismo da época: aprofundar as informações, principalmente sobre política. Daí se justificam as entrevistas com candidatos às eleições presidenciais de 1989, momento em que o país celebrava a volta das eleições diretas. Com seu percurso em programas humorísticos e sua relação com a sátira política, Jô Soares firmava-se na cena televisiva nacional como uma figura de ampla credibilidade, pois, por meio de suas piadas, levava os políticos a uma posição de constrangimento. Dessa forma, o Jô Soares Onze e Meia representou um ponto de passagem na história dos programas de entrevista e na configuração de um novo gênero: à proposta de aprofundamento e visibilidade a fontes não tão 
exploradas midiaticamente, o Jô Soares Onze e

Meia acrescentava o humor e o entretenimento.

0 embaralhamento entre informação e entretenimento assistido hodiernamente em diversos produtos inclusive nos talk shows chama atenção para 0 fato de que 0 entretenimento é um valor das sociedades contemporâneas que se organiza em forma de indústria e que cria estratégias para atrair a atenção da audiência (GOMES, 2008), e implica colocar o prazer como referencial para a sociedade e, por conseguinte, para 0 jornalismo. Deste modo, as relações entre talk shows e programas de entrevista na grade de programação televisiva permitem estender o jornalismo televisivo, de modo a inserir 0 entretenimento como uma forma de recepção igualmente legítima na sociedade contemporânea ${ }^{7}$. Alguns autores têm dedicado um esforço em atribuir ao talk show um caráter relevante, ainda que seja marcado pelo infotainment. Sonia Livingstone e Peter Lunt afirmam que os talk shows "desafiam concepções existentes de gênero, particularmente na distinção entre entretenimento e informação, ideias e emoções, argumento e narrativa" (1994, p. 37). Segundo os autores, é nos talk shows que a dimensão de esfera pública habermasiana se abre para discussão da audiência sobre assuntos relativos à sua vida cotidiana.
No Brasil, o talk show não rechaçou

completamente uma ligação com o campo jornalístico mais tradicional, fazendo referência à dimensão de interesse público e vigilância, e é nesse sentido que podemos pensar o Programa do Jô, que vai ao ar de segunda a sexta, pela Rede Globo e pela rádio CBN após a exibição do Jornal da Globo, último telejornal nacional transmitido pela emissora. À frente do programa, encontramos Jô Soares, uma figura que construiu sua carreira televisiva tanto em programas de humor - dentre os quais Família Trapo, Satiricom, Faça Humor, Não Faça Guerra e Viva o Gordo - quanto na sátira política. Além disso, Jô Soares é roteirista, diretor teatral e ator. É por meio dessa justaposição de elementos que o Programa do Jô irá construir seu tom e estilo, aqui definido como modo de endereçamento.

\section{Tom e estilo do Programa do Jô}

0 conceito de modo de endereçamento, embora tenha nascido da screen theory, desenvolveu-se nos Estudos Culturais para designar um tipo de cumplicidade estabelecida pelo programa em direção à sua audiência. Foram David Morley e Charlote Brunsdon (1999) que perceberam, na pesquisa empírica com os receptores do programa Nationwide, que os telespectadores do programa o interpretam a partir de seu "modo de dizer" e não somente pelos conteúdos e ideologia

Programas como o Marília Gabriela Entrevista, do GNT, são um exemplo de como certas dimensões do entretenimento, mais marcadamente a subjetividade e a cotidianidade, fazem funcionar um diálogo saudável com o jornalismo. Sobre o divertimento como forma de recepção das sociedades contemporâneas, ver Benjamim (1982). 
transmitidos. Nas palavras de Itania Gomes (2007), o modo de endereçamento

[...] nos diz, duplamente, da orientação de um programa para 0 seu receptor e de um modo de dizer específico; da relação de interdependência entre emissores e receptores na construção do sentido de um produto televisivo e do seu estilo. Nessa perspectiva, o conceito de modo de endereçamento se refere ao modo como um determinado programa se relaciona com sua audiência a partir da construção de um estilo, que 0 identifica e que 0 diferencia dos demais (2007, p. 17).

A atualização desse modo de endereçamento se dá pela articulação de quatro operadores: mediador, pacto sobre o papel do jornalismo, temática e organização das editorias, e contexto comunicativo (GOMES, 2007). No Programa do Jô, os intercâmbios entre informação e entretenimento se expressam no modo de endereçamento: mediador e pacto sobre o papel do jornalismo se articulam numa tentativa do programa de se legitimar no campo televisivo, enquanto a temática e o contexto comunicativo requerem do telespectador um hábito de audiência de programas que se estruturam em torno da lógica do entretenimento $0^{8}$.

O Programa do Jô utiliza um jornalismo de atração, modelo definido por Mats Ëkström (2000) como uma forma de comunicação emergente da atualidade nas quais os programas jornalísticos televisivos buscam chamar a atenção da audiência para aumentar a lucratividade das emissoras. Para Ekström, um dos elementos que permitem identificar o jornalismo de atração é a estética do programa baseada em imagens expressivas e dramáticas, cores brilhantes, recursos sonoros e participação de uma plateia. No Programa do Jô, há a criação de uma "situação comunicativa concreta" que corrobora com essa perspectiva, na medida em que posiciona o telespectador como se estivesse em um espetáculo cômico. É pela partilha de uma experiência exterior à cena televisiva que o talk show comandado por Jô Soares cria um contexto comunicativo no qual a posição do telespectador é de participante de um show de comédia. De acordo com Gomes, o contexto comunicativo "compreende tanto emissor, quanto receptor e mais as circunstâncias espaciais e temporais em que o processo comunicativo se dá" (2007, p. 19).

0 programa inicia ao som do Sexteto, grupo de instrumentistas responsável pela música do programa, enquanto o apresentador caminha até 0 centro do palco sob aplausos da plateia. A música é interrompida com um gesto feito pelo apresentador e assim se inicia a emissão com uma série de anedotas e piadas contadas pelo mediador. Visivelmente inspirado no americano Late Night with David Letterman, exibido no Brasil pelo GNT, o Programa do Jô reproduz a referência à vida urbana noturna representada 
no cenário com uma ampla imagem dos arranhacéus de São Paulo; o grupo de músicos que obedecem aos comandos do mediador; a presença de um "mordomo de palco" - Alex; a plateia; e a performance do mediador que atua como um animador contando anedotas e piadas.

Para Ekström (2000), o jornalismo de atrações põe em relevo três atores: 0 jornalista que está no controle e organiza o programa, o convidado e a plateia. No que diz respeito ao controle do programa, Jô Soares é imprescindível de forma que, quando entra em férias, a atração sofre uma pausa e é substituída na grade de programação por edições passadas ou por seriados norteamericanos. Segundo Itania Gomes, é o mediador dos produtos jornalísticos televisivos que fornece a cara do programa e estabelece uma relação com os telespectadores e os demais integrantes do programa (2007, p. 18). No Programa do Jô, 0 apresentador centraliza a função de "dono da cena", concentrando nele o controle da emissão do programa. Frequentemente, ele pede que um câmera mostre uma imagem e faz referência a alguém que está na produção do programa, quando diz: "Vini, roda a nossa vinhetinha".

Comparados com Jô Soares, os convidados tornam-se um elemento secundário na cena, um objeto que cede ainda mais saliência ao papel do apresentador. A sua postura diante dos convidados é de uma permanente negociação por maior espaço de fala, de modo a explorar os aspectos mais curiosos e humorísticos de cada entrevistado servindo de pretexto para suas performances. Segundo uma pesquisa publicada pela Folha de São Paulo, em abril de 2002, Jô Soares, em comparação com outros apresentadores de talk show e programas de entrevista, concentra muito mais tempo de fala: Jô discorre por $44,4 \%$ do tempo de suas entrevistas. Seus convidados comparecem com $55,6 \%$. A cronometragem, feita pela Folha entre 2 e 5 de abril, semana de reestreia do 'Programa do Jồ' na Globo, não contabilizou a abertura, as piadas no início de cada bloco nem os musicais. Comparado a seus colegas de 'talk shows' diários, Jô fala bem mais. Marília Gabriela (Rede TV!, 23h) monopoliza 28\% das conversas e 0 norte-americano David Letterman (GNT, 22h), 28,2\% (FINOTTI, 2002).

Embora o programa seja construído para fazer parecer que a conversa se dá de igual para igual, percebe-se um comportamento do mediador como se quisesse colocar-se numa posição de superioridade, corroborando ainda mais para sua centralidade no programa. A superioridade se mostra nas anedotas sobre os erros cometidos por estudantes brasileiros do ensino médio ${ }^{9}$, superioridade também no tratamento a Alex, que é colocado como serviçal. Frequentemente, 0 apresentador demonstra que tem tanto ou mais conhecimento que seu entrevistado, corrigindo-0 
ou repetindo o que ele diz. Tal conhecimento não se traduz em dados fornecidos pelo apresentador ou na referência a alguma fonte pesquisada, mas tão somente em sua opinião subjetiva. Para mostrar-se conhecedor de todas as esferas sociais, 0 apresentador recorre à sua experiência como ator e diretor teatral, à sua carreira no Pasquim e em outros veículos jornalísticos, revelando alguma vinculação, ainda que seja pessoal, com o convidado e o tema. É comum, durante a entrevista, 0 apresentador referir-se às pessoas como "a minha amiga Gisele [Bunchen, modelo] (29 nov. 2006) ou "eu conheci muito o Tarso [de Castro, jornalista]" (29 nov. 2006), "eu acho o Eriberto [Desmonte, músico] um músico excepcional" (10 out. 2006).

A plateia, por sua vez, promove uma espécie de interlocução (ainda que restrita) à performance do apresentador. Formada majoritariamente por estudantes universitários de todo o país que se inscrevem para participar, a plateia se engaja na cena por meio de suas reações: riso, silêncio, aplausos. É para ela que Jô dirige sua atuação teatral, estabelecendo um vínculo que se inicia desde as anedotas iniciais perpassando por todas as entrevistas quando olha diretamente para os integrantes sentados na arquibancada para mostrar uma reação de surpresa ou ironia com relação à fala de um entrevistado. É direcionando-se à plateia que Jô Soares faz graça e recebe em retorno os sorrisos e aplausos de seus espectadores. É deste modo que o programa busca construir um lugar para o telespectador, como se ele fosse uma extensão da plateia, uma vez que a câmera que capta essa graça fica, justamente, à frente da arquibancada.

Segundo Mats Ekström (2000), o jornalismo de atrações é voltado para os acontecimentos midiáticos criados pela própria televisão. No Programa do Jô, a temática dominante gira em torno dos lançamentos de produtos culturais: 0 novo $\mathrm{CD}$, a nova peça, a última telenovela, o DVD recém-lançado. Embora o programa não possua uma organização temática (as entrevistas não se relacionam por meio de um tema geral), é possível notar um tratamento privilegiado aos assuntos que emergem da mídia. Dessa forma, 0 programa constrói-se como uma auto-referência ao próprio campo midiático. Cada vez mais o programa comandado por Jô Soares tem-se tornado, também, um espaço de apresentação em que bandas com pouca visibilidade midiática se apresentam no quadro Canja do Jô. Os próprios entrevistados são convidados a encenarem uma parte de seus espetáculos ou levam imagens com trechos de filmes, minisséries ou telenovelas dos quais fizeram parte. Deste modo, o programa não solicita do entrevistado um conhecimento prévio sobre 0 entrevistado, uma vez que é no contexto daquela emissão que o telespectador é apresentado ao produto. Sendo assim, o Programa do Jô "cria acontecimentos na mídia, para a mídia e para ativar um tipo específico de envolvimento da audiência na mídia" (EKSTRÖM, 2000, p. 480, grifo do autor). 
0 principal valor-notícia das atrações, segundo Ekström (2000), é a singularidade definida por Traquina (2005) como algo que sai da normalidade da vida cotidiana. Embora não seja seu principal valor-notícia, é na construção do curioso, do inesperado que o Programa do Jô abre espaço à pessoa comum que passou por uma situação inusitada, como o porteiro que virou síndico de um condomínio.

Para Mats Ekström (2000), as atrações envolvem um modo de recepção em que a audiência espera da TV não informação e reflexão, mas que desperte novas e imediatas emoções, que provoque o riso e o choro, que surpreenda e entretenha. 0 principal veículo por meio do qual o programa efetiva esse caráter é a exposição da vida privada das celebridades. Jô Soares enquadra as entrevistas (ENTMAN, 1993) focando, sobretudo, no elemento pessoal que, no caso do Programa do Jô, pouco contribui para uma discussão mais ampla dos assuntos. Essa ênfase na vida privada fica nítida quando o mediador inicia a conversa demandando do entrevistado um bate-papo sobre algo pessoal, construindo para ele uma posição de amigo íntimo. Na entrevista com a jornalista Lílian Pacce (29 nov. 2006), Jô Soares, após elogiar a capa do livro que ela estava divulgando, iniciou a conversa: "tudo bem com você? Quanto tempo? A última vez que a gente se viu foi no Cirque du Soleil. Teu marido [o jornalista Leão Serva] passou, eu estava com um refletor na cara, nem vi. Ele falou 'oi, tudo bem, Jô?', eu: 'tudo bem', nem reconheci. Como é que ele vai?".
A publicização do privado que é compactuada pelos convidados e esperada pelos telespectadores configura-se como elemento principal da conversa estabelecida entre 0 Programa do Jô e seus telespectadores. Assim, 0 programa conta com uma série de depoimentos que não necessariamente visam chegar a algum lugar, ratificando aquilo que Daniel Dayan (2006) caracterizou como televisão cerimonial, em que mostrar é mais importante que demonstrar. Os testemunhos, segundo Dayan, não necessariamente suscitam o debate, reduzindo-se à experiência pessoal que ninguém pode refutar.

Um especialista pode contradizer outro. Mas ao contrário, um especialista não pode contradizer o testemunho de alguém já que se refere a sua própria experiência. Ele não pode dizer a esse testemunho: essa não é a sua experiência, essa não é a sua vivência, você não sabe exatamente do que está falando, eu conheço sua experiência melhor que você (DAYAN, 2006, p. 180).

É por meio do acesso à vida privada que 0

Programa do Jô sugere ao telespectador uma forma de recepção que privilegia o riso pelo riso, pelo prazer e pelo divertimento.

Tal posicionamento da audiência contrasta, entretanto, para 0 apelo a uma outra forma de comunicação caracterizada por Ekström (2000) como jornalismo de informação, modelo cuja intenção central é fornecer conhecimento por meio de notícias sobre assuntos relevantes de interesse público, construindo-se como o pilar da auto-legitimação do jornalismo. Aproximando-se desse sentido é que o Programa do Jô vai acessar 
retoricamente valores típicos do jornalismo a fim de legitimar-se na grade de programação. Segundo Itania Gomes, é no pacto sobre o papel do jornalismo que os programas atualizam as premissas de verdade, relevância, interesse público, vigilância, atualidade entre outras que indicam ao telespectador que tipo de jornalismo se pode esperar (2007, p. 19-20).

As estratégias pelas quais o programa se constrói dessa forma são muitas. Primeiro, pela referência à própria trajetória do mediador, que se construiu no humor satírico sobre assuntos políticos. Muitas vezes, Jô Soares evoca sua bagagem no campo televisivo quando se refere às mais de dez mil entrevistas que já realizou. Essa referência inclui o trabalho no SBT, e é o que confere ao mediador credibilidade, construída num cenário sócio-político muito distinto do atual, para ocupar a posição que ocupa no programa e na televisão, pois sua trajetória transcende a emissora, o que, retoricamente, lhe garante certa independência. Assim, o programa requer do telespectador um repertório televisivo que lhe permita fazer esse tipo de deslocamento.

Em segundo lugar, há uma ampliação da temática a assuntos que estejam em pauta na agenda midiática, classificada pelo apresentador como "serviço público" e "interesse público", expressões que carregam certos valores do jornalismo. Para tratar desses assuntos, Jô Soares leva para 0 estúdio fontes especializadas como psiquiatras, médicos, cientistas e pesquisadores que têm como função transmitir um conhecimento.
Frequentemente essas entrevistas ganham dois blocos de exibição e Jô Soares cumpre o papel de porta-voz das curiosidades e dúvidas da audiência. É através desse compromisso com a audiência que o Programa do Jô presta esclarecimento sobre as opções organizacionais (fazer ou não uma entrevista, incluir ou não um quadro) e presta contas sobre acusações que afetem a credibilidade do programa.

Outra estratégia é 0 acesso às personalidades da política, campo intrinsecamente ligado ao discurso auto-evidente do jornalismo desde sua institucionalização no século XIX (DALGHREN, 2000). Em 2005, com os escândalos que envolveram o pagamento do "mensalão" aos deputados federais, o Programa do Jô criou uma edição especial que ia ao ar às quartas-feiras com jornalistas e cientistas políticas formando uma mesa para falar sobre esse tema. A essa edição especial 0 apresentador chamou "Meninas do Jô", o que criou uma nova relação com a audiência. Valendo-se do passado do mediador como entrevistador de personalidades políticas ainda no Jô Soares Onze e Meia, o Programa do Jô tentou estear um pacto sobre o papel do jornalismo: 0 de um programa que, para além do humor, propõe-se a discutir assuntos importantes da esfera pública para um público intelectualizado. Com o quadro das Meninas do Jô e com as entrevistas realizadas com deputados para falar sobre o mensalão, o Programa do Jô criou uma aproximação com o jornalismo por tratar detidamente de um tema reconhecido socialmente como de interesse público. 


\section{Considerações finais}

Do mesmo modo que o talk show permite estender os limites do gênero jornalismo televisivo trazendo a subjetividade e a diversão como parâmetros para construção da informação, no Brasil a informatividade característica do campo jornalístico tem ainda um peso de autenticação muito forte em sua forma de construção, como se, para serem reconhecidos socialmente, precisassem tangenciar de algum modo as premissas do jornalismo. Tal postura, ao invés de amenizar, reforça a visão preconceituosa sobre o infotainment, já que promove uma descontinuidade na estruturação do programa.

Nos Estados Unidos, hoje, já existem talk shows que se constroem com base no humor e na diversão que são legítimos diante da audiência.

0 The Daily Show, programa comandado por John Stewart, simula os procedimentos jornalísticos com uma bancada, um falso repórter, enviados especiais e uma entrevista ${ }^{10}$. Apesar de não ser um talk show, estreou em março deste ano o $\mathrm{CQC}^{11}$ (Custe o que Custar) pela TV Bandeirantes, que instituiu um "jornalismo de escracho" por meio da cobertura política, das denúncias a órgãos públicos e da sátira ao próprio jornalismo, informando enquanto diverte. Esses programas nos fazem refletir sobre a construção de programas baseados no infotainment que podem suscitar reflexão tendo o humor como ingrediente principal, sendo legitimados pelas estratégias internas ao próprio gênero.

\section{Referências:}

BARBER0, Jesús-Martín. América Latina e os anos recentes: 0 estudo da recepção em comunicação social. In: SOUSA, Mauro Wilton (org.). Sujeito, o lado oculto do receptor. São Paulo: Brasiliense, 1995, 39-68.

BARBERO, Jesús-Martín. Dos meios às mediações: comunicação, cultura e hegemonia. Rio de Janeiro: UFRJ, 1997.

BAYM, Geoffrey. The Daily Show and the reinvention of political journalism. In: ANNUAL PRE-APSA CONFERENCE ON POLITICAL COMMUNICATION. 3., 2004, Chicago. Anais...Chicago, 2004. Disponível em: <http://tigger.uic.edu/depts/pols/PolComConf/ BaymTheDailyshow.pdf>. Acesso em: 3 jun. 2008.

BENJAMIN, Walter. A obra de arte na época de sua reprodutibilidade técnica. In: LIMA, Luiz Costa (org).

Teoria da Cultura de Massa. 3.ed. Rio de Janeiro: Terra e Paz, 1936-1982. p. 09-240.

CAETANO, Maria João. The Daily Show: um noticiário de mentira que diverte e informa. Disponível em: $<$ http://dn.sapo.pt/2004/11/15/media/the_daily_show_ noticiario_de_mentira.html>.Acesso em: 4 out. 2008.

CHALABY, Jean. 0 jornalismo como invenção angloamericana. Comparação entre o desenvolvimento do jornalismo francês e anglo-americano (18301920). Media \& Jornalismo, Londres, vol. 1, n. 3, p. 29-50, 2003. Disponível em: <http://revcom. portcom.intercom.org.br/scielo.php?script=sci_

10 Inúmeras informações sobre o The Daily Show existem disponíveis na Internet. Para uma discussão mais aprofundada, ver Baym (2004).

110 CQC é um formato importado da Argentina que se disseminou por diversos países. No Brasil a atração da Band conseguiu o terceiro lugar em audiência (Disponível em: <http://www1.folha.uol.com.br/folha/ilustrada/ult90u405829.shtml>. Acesso em: 04 out. 2008). 
arttex\&pid=S1645-56812003000300004\&Ing=pt\&n $\mathrm{rm}=$ iso\&tlng=pt $>$. Acesso em: 20 maio 2006. Artigo originalmente publicado no European Journal of Communication, vol. II, n. 3, 1996.

CHANDLER, Daniel. Semiotics for beginners Disponível em: <www.aber.ac.uk/media/Documents/ S4B/semiotc.html>. Acesso em: 15 ago. 2003.

DALHGREN, Peter. Journalism as popular culture. In: Journalism and popular culture. London, Sage, 2000. p. 1-23.

DAYAN, Daniel. Quand montrer c'est faire. In: La terreur spetacle. Paris, 2006. p. 165-184.

DUARTE, Elizabeth Bastos. Televisão: ensaios metodológicos. Porto Alegre: Sulina, 2004.

ENTMAN, Robert. Framing: toward clarification of fractured paradigm. Jornal of Communication, vol. 43, n. 4, p. 51-58, 1993.

EKSTRÖM, Mats. Information, storytelling and attractions: TV journalism in three modes of communication. Media, Culture \& Society, vol. 22, p. 465-492, 2000.

FINOTTI, I. Jô Soares tagarela. [S.I.]: Observatório da Imprensa, 2002. Disponível em: <http:// observatorio.ultimosegundo.ig.com.br/artigos/ asp240420024.htm>. Acesso em: 12 nov. 2007.

GOMES, Itania. Questão de método na análise do telejornalismo: premissas, conceitos, operadores de análise. E-compós, Brasília, vol. 2, p. 1-31, abr. 2007. A noção de gênero televisivo como estratégia de interação: 0 diálogo entre os cultural studies e os estudos da linguagem. Revista Fronteiras, São Leopoldo, p. 11-28, dez. 2002.

0 embaralhamento de fronteiras entre informação e entretenimento e a consideração do jornalismo como processo cultural e histórico. 2008. Texto em circulação restrita.
GOMES, Wilson. Jornalismo e esfera civil: o interesse público como princípio moral do jornalismo. In: PERUZZ0, Cicília (org). Comunicação para a Cidadania. Salvador: UNEB; São Paulo: INTERCOM, 2003. p. 28-51.

GOMES, Wilson. Transformações da política na era da comunicação de massa. São Paulo: Paulus, 2004.

GUERRA, Josenildo Luiz. 0 percurso interpretativo na produção da notícia. 2003. Tese (Doutorado em Comunicação e Cultura Contemporânea)- Programa de Pós-Graduação em Comunicação e Cultura Contemporâneas, Universidade Federal da Bahia, Salvador, 2003

IMPRENSA. Making of: o rei e suas damas. 2006.

Disponível em: <http://portalimprensa.uol.com.br/ new_ultimasnoticias_data_view.asp?code=2174>. Acesso em: 31 mar. 2007.

JOST, François. "Le Journal Télévisé". In:

Introduction à l'analyse de la television. 2.ed. Paris: Ellipses Édition Marketing, 2004a, p. 75-102.

JOST, François. Seis lições sobre televisão. Porto Alegra: Sulina, 2004b.

\section{LIVINGSTONE, Sonia M.; LUNT, Peter. Talk on} television: audience participation and public debate. London: Routledge, 1994.

MACHAD0, Ida Lúcia. Análise discursiva de um gênero televisual: a entrevista no talk show Jô Soares 11 e Meia. In: CARNEIR0, Agostinho Dias (org.). 0 Discurso da Mídia. Rio de Janeiro: Oficina do Autor, 1996. p. 99-124.

MATEU, Manuel. La entrevista en televisión. In: BALSEBRE, Armand; ; VIDAL, David. La entrevista em radio, televisión y prensa. Madrid: Cátedra, 1998. p. 149-244.

MILLER, Stephen. Conversation: a history of a declining art. New York: Vail-Ballou Press, 2006. 
MORLEY, David; BRUNSDON, Charlott. The Nationwide

Television Studies. London: Routledge, 1999.

ÖRNEBRING, Henrik. Televising the public sphere:

forty years of current affairs debate programmes

on Swedish television. European Journal of

Communication, vol. 18, n. 4, p. 501-527, 2003.

PRADO, Miguel Arcanjo. Humor do CQC dobra

audiência da Band. Disponível em: <http://wwwl.

folha.uol.com.br/folha/ilustrada/ult90u405829.shtml>. Acesso em: 4 out. 2008.

REZENDE, Guilherme Jorge de. Telejornalismo no

Brasil: um perfil editorial. São Paulo: Summus, 2000.

SHUSTERMAN, Richard. Entertainment: a question for aesthetics. British Journal of Aesthetics, vol. 43, n. 3, p. 289-307, Jul. 2003.

TIMBERG, Bernard M. Television talk: a history of the TV talk show. Texas: University of Texas, 2004.

TRAQUINA, Nelson. Teorias do jornalismo. A

tribo jornalística - uma comunidade interpretativa

transnacional. Florianópolis: Insular, 2005.

WILLIAMS, Raymond. Gêneros. In: Marxismo

e Literatura. Tradução: Waltensir Dutra. Rio de Janeiro: Zahar, 1971. p. 179-184. 
Talk show: a television genre between journalism and entertainment

\section{Abstract}

While in English speaking countries the term "talk show" is used to designate programs, whether journalistic or not, which revolve around conversation between participants, in Brazil the expression "talk show" represents a cross between the genres journalism and entertainment. The objective of this article is to carry out a historical analysis of the genre talk show in Brazil, and to demonstrate analytically the elements that configure this type of program as a television genre, by means of observation of the Programa do Jô (Globo television network). The historical analysis seeks to demonstrate the development of this genre from interview programs and the socio-cultural factors of Brazilian society that enabled the boundary between information and entertainment to become blurred, to become what is commonly called infotainment today. The analysis of the program will take into consideration the concept of modes of address, thinking in terms of the tone and style of the program.

\section{Keywords}

Talk show. Television genre. Infotainment.

\section{Talk show: un género televisivo entre el periodismo y el entretenimiento}

\section{Resumen}

Mientras que en los países de lengua inglesa el término "talk show" se emplea para designar programas, periodísticos o no, en los que la característica fundamental es la charla entre participantes, en Brasil, la nomenclatura "talk show" representa un corte entre la esfera del periodismo y del entretenimiento. El objetivo del presente artículo es rescatar desde el punto de vista histórico el surgimiento del género talk show en Brasil y demostrar analíticamente los elementos que lo configuran como género televisivo por medio de la observación del Programa do Jô (Red Globo). La recuperación histórica propone demostrar su desdoblamiento a partir de los programas de entrevistas y los factores socioculturales de la sociedad brasileña que permitieron borrar las fronteras entre información y entretenimiento, hoy comúnmente llamado infotainment. El análisis del programa tomará en cuenta el concepto de modos de direccionalidad, enfocado como tono y estilo del programa.

\section{Palabras clave}

Talk show. Género televisivo. Infotainment. 


\section{Expediente}

A revista E-Compós é a publicação científica em formato eletrônico da Associação Nacional dos Programas de Pós-Graduação em Comunicação (Compós). Lançada em 2004, tem como principal finalidade difundir a produção acadêmica de pesquisadores da área de Comunicação, inseridos em instituições do Brasil e do exterior.
E-COMPÓS I www.e-compos.org.br I E-ISSN 1808-2599

Revista da Associação Nacional dos Programas de Pós-Graduação em Comunicação. Brasília, v.12, n.1, jan./abr. 2009.

A identificação das edições, a partir de 2008 passa a ser volume anual com três números.

\section{CONSELHO EDITORIAL}

\section{Afonso Albuquerque}

Universidade Federal Fluminense, Brasil

Alberto Carlos Augusto Klein

Universidade Estadual de Londrina, Brasi

Alex Fernando Teixeira Primo

Universidade Federal do Rio Grande do Sul, Brasil

\section{Alfredo Vizeu}

Universidade Federal de Pernambuco, Brasil

Ana Carolina Damboriarena Escosteguy

Pontifícia Universidade Católica do Rio Grande do Sul, Bras

Ana Silvia Lopes Davi Médola

Universidade Estadual Paulista, Brasil

André Luiz Martins Lemos

Universidade Federal da Bahia, Brasil

Ângela Freire Prysthon

Universidade Federal de Pernambuco, Brasil

Antônio Fausto Neto

Universidade do Vale do Rio dos Sinos, Brasil

Antonio Carlos Hohlfeldt

Pontifícia Universidade Católica do Rio Grande do Sul, Brasil

Arlindo Ribeiro Machado

Universidade de São Paulo, Brasil

César Geraldo Guimarães

Universidade Federal de Minas Gerais, Brasil

Cristiane Freitas Gutfreind

Pontifícia Universidade Católica do Rio Grande do Sul, Brasil

Denilson Lopes

Universidade Federal do Rio de Janeiro, Brasil

Eduardo Peñuela Cañizal

Universidade Paulista, Brasi

Erick Felinto de Oliveira

Universidade do Estado do Rio de Janeiro, Brasil

Francisco Menezes Martins

Universidade Tuiuti do Paraná, Brasil

Gelson Santana

Universidade Anhembi/Morumbi, Brasi

Hector Ospina

Universidad de Manizales, Colômbia

leda Tucherman

Universidade Federal do Rio de Janeiro, Brasil

Itania Maria Mota Gomes

Universidade Federal da Bahia, Brasil

Janice Caiafa

Universidade Federal do Rio de Janeiro, Brasil

Jeder Silveira Janotti Junior

Universidade Federal da Bahia, Brasil

\section{João Freire Filho}

Universidade Federal do Rio de Janeiro, Brasil

John DH Downing

University of Texas at Austin, Estados Unidos

José Luiz Aidar Prado

Pontifícia Universidade Católica de São Paulo, Brasil

José Luiz Warren Jardim Gomes Braga

Universidade do Vale do Rio dos Sinos, Brasil

Juremir Machado da Silva

Pontifícia Universidade Católica do Rio Grande do Sul, Brasil

Lorraine Leu

University of Bristol, Grã-Bretanha

Luiz Claudio Martino

Universidade de Brasília, Brasil

Maria Immacolata Vassallo de Lopes

Universidade de São Paulo, Brasil

Maria Lucia Santaella

Pontifícia Universidade Católica de São Paulo, Brasil

Mauro Pereira Porto

Tulane University, Estados Unidos

Muniz Sodre de Araujo Cabral

Universidade Federal do Rio de Janeiro, Brasil

Nilda Aparecida Jacks

Universidade Federal do Rio Grande do Sul, Brasil

Paulo Roberto Gibaldi Vaz

Universidade Federal do Rio de Janeiro, Brasil

Renato Cordeiro Gomes

Pontifícia Universidade Católica do Rio de Janeiro, Brasil

Ronaldo George Hela

Universidade do Estado do Rio de Janeiro, Brasil

Rosana de Lima Soares

Universidade de São Paulo, Brasil

Rossana Reguillo

Instituto Tecnológico y de Estudios Superiores do Occidente, México

Rousiley Celi Moreira Maia

Universidade Federal de Minas Gerais, Brasil

Sebastião Carlos de Morais Squirra

Universidade Metodista de São Paulo, Brasi

Simone Maria Andrade Pereira de Sá

Universidade Federal Fluminense, Brasil

Suzete Venturelli

Universidade de Brasília, Brasil

Valério Cruz Brittos

Universidade do Vale do Rio dos Sinos, Brasil

Veneza Mayora Ronsini

Universidade Federal de Santa Maria, Brasil

Vera Regina Veiga França

Universidade Federal de Minas Gerais, Brasil
COMISSÃO EDITORIAL

Ana Gruszynski I Universidade Federal do Rio Grande do Sul, Brasil

Rose Melo Rocha I Escola Superior de Propaganda e Marketing, Brasil

CONSULTORES AD HOC

Alberto Schneider I Visitante Tokyo University

Alexandre Rocha da Silva I Universidade Federal do Rio Grande do Sul, Brasil

Fernanda Bruno I Universidade Federal do Rio de Janeiro, Brasil

Ida Stumpf I Universidade Federal do Rio Grande do Sul, Brasil

Kati Caetano I Universidade Tuiuti do Paraná, Brasil

Laura Cánepa I Universidade Anhembi Morumbi, Brasi

Malena Contrera I Universidade Paulista, Brasil

Sandra Gonçalves I Universidade Federal do Rio Grande do Sul, Brasil

Vicente Gosciola I Universidade Anhembi Morumbi, Brasil

REVISÃO DE TEXTO E TRADUÇÃo I Everton Cardoso

EDITORAÇ̃̃o ELETRÔNICA I Raquel Castedo
COMPós I www.compos.org.br

Associação Nacional dos Programas de Pós-Graduação em Comunicação

Presidente

Erick Felinto de Oliveira

Universidade do Estado do Rio de Janeiro, Brasil erickfelinto@uol.com.br

Vice-presidente

Ana Silvia Lopes Davi Médola

Universidade Estadual Paulista, Brasil

asilvia@faac.unesp.br

Secretária-Geral

Denize Correa Araújo

Universidade Tuiuti do Paraná, Brasil

denizearaujo@hotmail.com 